\title{
2,3,7,8-tetrachlorodibenzo- $p$-dioxin suppresses the growth of human colorectal cancer cells in vitro: Implication of the aryl hydrocarbon receptor signaling
}

\author{
MASAYOSHI YAMAGUCHI ${ }^{1}$ and OLIVER HANKINSON ${ }^{1,2}$ \\ ${ }^{1}$ Department of Pathology and Laboratory Medicine, ${ }^{2}$ Molecular Toxicology Program, \\ David Geffen School of Medicine, University of California, \\ Los Angeles (UCLA), Los Angeles, CA 90095-1732, USA
}

Received August 29,2018; Accepted December 18, 2018

DOI: 10.3892/ijo.2019.4703

\begin{abstract}
Human colorectal cancer is the third most common cancer disease with a 5-year survival rate of 55\% in USA in 2016. The investigation to identify novel biomarker factors with molecular classification may provide notable clinical information to prolong the survival of patients with colorectal cancer. The aryl hydrocarbon receptor (AHR) binds the AHR nuclear translocator in the cytoplasm of various types of cells, including liver cells, and then binds to the xenobiotic responsive element on various genes. AHR was initially discovered via its ligand, the polychlorinated hydrocarbon, 2,3,7,8-tetrachlorodibenzo-p-dioxin (TCDD). The present study was undertaken to determine whether TCDD, an agonist of AHR signaling, impacts the growth of RKO human colorectal cancer cells in vitro. Treatment with TCDD (0.1-100 $\mathrm{nM})$ revealed suppressive effects on colony formation and proliferation of RKO cells, and stimulated death of these cells with subconfluence. These effects of TCDD were abolished by pretreatment with CH223191, an inhibitor of AHR signaling. Western blot analysis demonstrated that TCDD treatment decreased AHR levels and elevated cytochrome P450 family 1 subfamily A member 1 (CYP1A1) levels, indicating a stimulation of AHR signaling. TCDD treatment caused an increase in nuclear factor- $\kappa \mathrm{B}$ p 65 and $\beta$-catenin levels, although it did not have an effect on Ras levels. Notably, TCDD treatment increased the levels of p53, retinoblastoma, p21 and regucalcin, which are depressors of carcinogenesis. Additionally, action of TCDD on cell proliferation and death were not revealed in regucalcin-overexpressing RKO cells,
\end{abstract}

Correspondence to: Dr Masayoshi Yamaguchi, Department of Pathology and Laboratory Medicine, David Geffen School of Medicine, University of California, Los Angeles (UCLA), 700 Tiverton Avenue, Los Angeles, CA 90095-1732, USA

E-mail: yamamasa11555@yahoo.co.jp

Key words: 2,3,7,8-tetrachlorodibenzo- $p$-dioxin, cell proliferation, cell death, colony formation, RKO cells, regucalcin, carcinogenesis and regucalcin overexpression depressed AHR signaling associated with CYP1A1 expression. Thus, AHR signaling suppresses the growth of colorectal cancer cells, indicating a role as a significant targeting molecule for colorectal cancer.

\section{Introduction}

Intestinal homeostasis is maintained by complex interactions between intestinal microorganisms and the gut immune system, and dysregulation of gut immunity may cause inflammation and tumorigenesis (1). Interaction between epithelial cells and stromal cells, including leukocytes and fibroblasts, is considered to be pivotal for tumorigenesis and cancer progression (1). Adenocarcinoma colorectal cancer is a predominant malignancy located in the colon and rectum, and it has been proposed to arise from a subpopulation of self-renewing tumor stem cells located within the tumor microenvironment $(1,2)$. Colorectal cancer is the third most common cancer diagnosed in USA in $2016(3,4)$ and its 5 -year survival rate remains poor at $55 \%$ (4). Colorectal cancer is a heterogeneous group of diseases, and its prognosis remains poor in spite of the development of novel therapeutic strategies (5-8), and its molecular classification is notable (5-9). The identification of novel biomarker targets is proposed to result in prolonged survival of patients with colorectal cancer (10).

The aryl hydrocarbon receptor (AHR) is a ligand-activated transcription factor, which is located in manifold types of cells $(11,12)$. AHR forms a heterodimer with the AHR nuclear translocator, which is transcriptionally active after binding to xenobiotic responsive elements in various genes, including the cytochrome P450 family 1 subfamily A member 1 (CYP1A1) gene $(11,12)$. The AHR was initially discovered in the process that investigates its binding to polychlorinated aromatic hydrocarbons, including 2,3,7,8-tetrachlorodibenzo-p-dioxin (TCDD) and polychlorinated biphenyls $(11,12)$. Numerous AHR ligands, as AHR agonists, have been identified, including synthetic and environmental chemicals, and naturally-occurring dietary and endogenous compounds (13-18). AHR signaling has been regulated through various signaling factors, including nuclear 
factor- $\kappa \mathrm{B}(\mathrm{NF}-\kappa \mathrm{B}) \mathrm{p} 65$, and it appears to serve an important role in the regulation of diverse cellular and biological processes (19). The canonical target genes for AHR are well known in cytochrome P450 isoforms (CYP1A1, CYP1A2 and CYP1B1), which are implicated in the metabolic pathway of xenobiotics and endogenous compounds located in tissues and cells $(20,21)$. The AHR signaling-dependent pathway is also implicated in manifestation of chemically-induced toxicity and carcinogenesis, which are induced through the production of free radicals and conversion of pro-carcinogens to ultimate genotoxic carcinogens via metabolism that is mediated by cytochrome P450 enzymes $(20,21)$. Furthermore, AHR ligands are involved in various pathologies in humans, resulting in toxic processes, including tumor promotion, immunosuppression and teratogenicity with disorder of the fine homeostatic regulations of cell functions (22-26).

The physiological role of AHR in the absence of exogenous ligand may serve a pivotal role in the regulation of cell function, compared with cellular impacts caused by its binding of exogenous ligand (27). Mice, which express a constitutively active AHR, exhibited a promoted development of hepatocarcinogenesis (28). Notably, AHR signaling may be demonstrated to serve a role of a depressor in the development of hepatocarcinogenesis (29). Furthermore, AHR signaling has been demonstrated to adjust liver repair and regeneration, and its signaling suppresses tumorigenesis by modulating the actions of stem-like cells and $\beta$-catenin signaling $(30,31)$. Recently, it was demonstrated that TCDD treatment represses the proliferation and promotes the death of human liver cancer HepG2 cells in vitro, and that the exhibition of these effects was implicated in AHR signaling associated with various signaling factors, including NF- $\mathrm{BB}$ p65 (32).

The AHR is expressed and characterized in human colon adenocarcinomacells, including RKO cells (33-35), and has been demonstrated to regulate the expression levels of CYP1A1 (36) and CYP1A2 (37) in colorectal cancer cells in vitro. The role of AHR thus has been reported in colon cancer cells (38). Notably, the AHR suppressed intestinal carcinogenesis in $\mathrm{Apc}^{\mathrm{Min} /+}$ mice following natural ligand treatment in vivo (39). Furthermore, the AHR is associated with tumor prevention by regulating gut immunity in normal intestinal tissues, and it is involved in growth suppression of tumor cells of $\mathrm{Apc}^{\mathrm{Min} /+}$ mice (16). Thus, the AHR may serve a repressive role in the development of colorectal cancer. However, the regulatory role of AHR signaling in the proliferation and death of human colorectal cancer cells is poorly understood. Therefore, this was investigated in $\mathrm{RKO}$ colorectal cancer cells in vitro. It was demonstrated that TCDD treatment suppresses the growth and proliferation, and stimulates the death of RKO cells, via AHR signaling. The observations indicated that the activation of AHR signaling serves a suppressive role in the development of human colorectal cancer, revealing a potential novel role of AHR as a target molecule in carcinogenesis.

\section{Materials and methods}

Materials. TCDD ( $>99.99 \%$ purity) was obtained from Dow Chemicals Co. (Midland, MI, USA), and it was dissolved in dimethyl sulfoxide (DMSO) and stored in the dark at $-20^{\circ} \mathrm{C}$ until use. Dulbecco's modified Eagle's medium (DMEM; including $4.5 \mathrm{~g} / 1$ glucose, L-glutamine and sodium pyruvate) and antibiotics (100 $\mu \mathrm{g} / \mathrm{ml}$ penicillin and $100 \mu \mathrm{g} / \mathrm{ml}$ streptomycin; P/S) were obtained from Corning Life Sciences (Manassas, VA, USA). Fetal bovine serum (FBS) was purchased from Omega Scientific Inc. (Tarzana, CA, USA). 2-methyl-2H-pyrazole-3-carboxylic acid (2-methyl-4-o-tolylazo-phenyl)-amide (CH223191) was purchased from Selleck Chemicals (Houston, TX, USA), and it was dissolved in 100\% DMSO. Caspase-3 inhibitor, crystal violet, and all other chemicals were obtained from Sigma-Aldrich (Merck KGaA, Darmstadt, Germany).

Human colorectal cancer cells. RKO epithelial cells, which originated from male adult patients with colorectal carcinoma, were used in the present study. This cell line was purchased from the American Type Culture Collection (Manassas, VA, USA). RKO cells were cultured in DMEM including 10\% FBS and $1 \% \mathrm{P} / \mathrm{S}$.

Assay of colony formation of RKO cells. RKO cells ( $1 \times 10^{3}$ cells/well per $2 \mathrm{ml}$ of medium in 6 -well plates) were cultured in DMEM containing $10 \% \mathrm{FBS}, 1 \% \mathrm{P} / \mathrm{S}$ and $1 \%$ fungizone in an atmosphere containing $5 \% \mathrm{CO}_{2}$ at $37^{\circ} \mathrm{C}$ in the presence of vehicle (1\% DMSO) or TCDD (1 or $10 \mathrm{nM})$ for 5 days, when visible clones formed on the plates $(40,41)$. Following the culture, the dishes were washed with PBS (3 times with $2 \mathrm{ml}$ ) and fixed with 100\% methanol (adding $0.5 \mathrm{ml}$ per well) for $20 \mathrm{~min}$ at room temperature, and then washed 3 times with PBS $(2 \mathrm{ml})$. The colonies were stained with crystal violet. Crystal violet solution $(0.5 \%$, dissolved in $20 \%$ methanol) was added to the fixed cells for $30 \mathrm{~min}$ at room temperature. Thereafter, stained cells were washed 5 times with PBS ( $2 \mathrm{ml})$. After washing, the plates were air-dried for $2 \mathrm{~h}$ at room temperature. The colonies (including $>50$ cells) were counted under a microscope (x10; Nikon Corporation, Tokyo, Japan) using a cell counter (Line Seiki H-102P; Line Seiki Co., Ltd., Tokyo, Japan). Data are represented as numbers of colonies per well.

Transfection of regucalcin cDNA/pCXN2 into RKO cells. To generate the regucalcin-overexpressing $\mathrm{RKO}$ cells, the RKO wild-type cells were transfected with empty pCXN2 vector (Addgene, Inc., Cambridge, MA, USA; $600 \mu \mathrm{g} / \mathrm{ml}$ ) or pCXN2 vector (Addgene, Inc.; $600 \mu \mathrm{g} / \mathrm{ml}$ ) expressing a cDNA encoding the human full-length $(900 \mathrm{bp}$ ) regucalcin (regucalcin cDNA/pCXN2) $(42,43)$. For transfection, the RKO cells (1x10\%/well per ml of DMEM) were grown on 24 -well plates to reach subconfluency. Regucalcin cDNA/pCXN2 (1 $\mu \mathrm{g} /$ well) or empty pCXN2 vector ( $1 \mu \mathrm{g} / \mathrm{well})$ alone was transfected into the RKO cells using the synthetic cationic lipid Lipofectamine ${ }^{\circledR}$ reagent, according to the manufacturer's protocols (Promega Corporation, Madison, WI, USA) (43). Following overnight incubation after transfection, Geneticin (600 $\mu \mathrm{g} / \mathrm{ml} \mathrm{G} 418$; Sigma-Aldrich; Merck KGaA) was added to the culture wells to select transfectants, and the cells were cultured in an atmosphere containing $5 \% \mathrm{CO}_{2}$ at $37^{\circ} \mathrm{C}$ for 3 weeks to produce transfected cells. Subsequently, the transfected cells were plated with limiting dilution to isolate transfectants using 96-well plates. Surviving clones were isolated, transferred to $35-\mathrm{mm}$ dishes, and grown in DMEM without Geneticin. 
The transfectant clones 1 and 2 exhibiting stable expression of regucalcin were then obtained. The levels of regucalcin expressed in two clones were assayed using western blot analysis, and those exhibited an elevation expression of 7.4or 10.9 -fold in clones 1 or 2 , respectively, compared with wild-type cells, respectively, as depicted in Fig. 6A. Therefore, clone 2 was used in the subsequent experiments.

Assay of cell proliferation. To determine the effect of TCDD on cell proliferation, the RKO wild-type cells $\left(1 \times 10^{5} / \mathrm{ml}\right.$ per well) were cultured using a 24-well plates in DMEM, containing $10 \% \mathrm{FBS}, 1 \% \mathrm{P} / \mathrm{S}$ and $1 \%$ fungizone, in the presence of vehicle (1\% DMSO) or TCDD $(0.1,1,10$ or $100 \mathrm{nM}$ ) in an atmosphere containing $5 \% \mathrm{CO}_{2}$ and $37^{\circ} \mathrm{C}$ for 3 or 7 days (44). In separate experiments, the RKO wild-type cells or transfectants $\left(1 \times 10^{5} / \mathrm{ml}\right.$ per well $)$ were cultured in DMEM containing $10 \% \mathrm{FBS}, 1 \% \mathrm{P} / \mathrm{S}$ and $1 \%$ fungizone with or without vehicle (1\% DMSO), TCDD $(1,10$ or $100 \mathrm{nM})$, or $\mathrm{CH} 223191(1$ or $10 \mu \mathrm{M})$ with or without TCDD $(10 \mathrm{nM})$ in an atmosphere containing $5 \% \mathrm{CO}_{2}$ and $37^{\circ} \mathrm{C}$ for 3 days. The RKO cells were then detached from each culture dish to determine cell number using a cell counter.

Assay of cell death. To determine the effect of TCDD on cell death, the RKO wild-type cells $\left(1 \times 10^{5} / \mathrm{ml}\right.$ per well $)$ were cultured using 24-well plates in DMEM, containing $10 \% \mathrm{FBS}, 1 \% \mathrm{P} / \mathrm{S}$, and $1 \%$ fungizone, in the absence of TCDD in an atmosphere containing $5 \% \mathrm{CO}_{2}$ and $37^{\circ} \mathrm{C}$ for 3 days in order to reach subconfluence. The cultured cells at subconfluency were incubated in the presence of vehicle (1\% DMSO) or TCDD $(0.1,1,10$ or $100 \mathrm{nM})$, with or without the caspase-3 inhibitor $(10 \mu \mathrm{M})$ in the presence of either vehicle or $\mathrm{CH} 223191$ $(1$ or $10 \mu \mathrm{M})$ for $24 \mathrm{~h}$ in an atmosphere containing $5 \% \mathrm{CO}_{2}$ at $37^{\circ} \mathrm{C}(45)$. In other experiments, the RKO-wild-type cells or transfectants $\left(1 \times 10^{5} / \mathrm{ml}\right.$ per well) were cultured in DMEM containing $10 \% \mathrm{FBS}, 1 \% \mathrm{P} / \mathrm{S}$ and $1 \%$ fungizone in the absence of TCDD in an atmosphere containing $5 \% \mathrm{CO}_{2}$ and $37^{\circ} \mathrm{C}$ for 3 days. After reaching subconfluence, the cells were incubated in the presence of vehicle (1\% DMSO), TCDD (1, 10 or $100 \mathrm{nM})$, or $\mathrm{CH} 223191(1$ or $10 \mu \mathrm{M})$ with or without TCDD $(10 \mathrm{nM})$ for $24 \mathrm{~h}$ in an atmosphere containing 5\% $\mathrm{CO}_{2}$ at $37^{\circ} \mathrm{C}(45)$. Cells were then detached from each culture well to determine cell number using a cell counter.

Counting of cell number. To detach cells attached on each well after culturing in order to assay the proliferation and death of RKO cells, culture dishes were incubated for $2 \mathrm{~min}$ at $37^{\circ} \mathrm{C}$ with the addition of a solution $(0.1 \mathrm{ml}$ per well $)$ of $0.05 \%$ trypsin plus EDTA in $\mathrm{Ca}^{2+} / \mathrm{Mg}^{2+}$-free PBS, and then cells were detached through pipetting after the addition of DMEM $(0.9 \mathrm{ml})$ containing $10 \% \mathrm{FBS}$ and $1 \% \mathrm{P} / \mathrm{S}$ into the wells $(44,45)$. The medium containing the suspended cells $(0.1 \mathrm{ml})$ was mixed with $0.1 \mathrm{ml}$ of $0.5 \%$ trypan blue staining solution $(44,45)$. The number of viable cells with viability was counted under a microscope (x10; Olympus MTV-3; Olympus Corporation, Tokyo, Japan) using a Hemocytometer plate (Sigma-Aldrich; Merck KGaA) and a cell counter (Line Seiki H-102P; Line Seiki Co., Ltd.). The mean of two counts was calculated for each dish. The number of cells is presented as number per well of the plate.
Western blot analysis. To determine levels of various proteins expressed in RKO cells, wild-type RKO cells or regucalcin-overexpressing cells were plated in 100x21 mm dishes at a density of $1 \times 10^{6}$ cells/dish in $10 \mathrm{ml}$ DMEM containing $10 \% \mathrm{FBS}, 1 \% \mathrm{P} / \mathrm{S}$ and $1 \%$ fungizone, and then cultured in the presence of vehicle (1\% DMSO) or TCDD $(10 \mathrm{nM})$ in an atmosphere containing $5 \% \mathrm{CO}_{2}$ and $37^{\circ} \mathrm{C}$ for 3 days. After culturing, the cells were washed three times with ice-cold PBS and removed from the dish by scraping after the addition of cell lysis buffer (Cell Signaling Technology, Inc., Danvers, MA, USA) supplemented with inhibitors of protease and protein phosphatase (Roche Diagnostics, Indianapolis, IN, USA). The collected lysates were centrifuged at $17,000 \mathrm{x} g$ at $4^{\circ} \mathrm{C}$ for $10 \mathrm{~min}$, to prepare fractions including the cytoplasm and endoplasmic reticulum of RKO cells. The concentrations of protein in aforementioned supernatants were assayed using the Bio-Rad Protein Assay Dye (Bio-Rad Laboratories, Inc., Hercules, CA, USA) with bovine serum albumin (Bio-Rad Laboratories, Inc.) as standard. The aforementioned supernatant from cell lysate was stored at $-80^{\circ} \mathrm{C}$ until use for western blot assay. Samples of $40 \mu \mathrm{g}$ supernatant protein were applied to each lane and were separated using SDS-PAGE (12\%). After electrophoresis, the gel was transferred onto PVDF membranes for immunoblotting with specific antibodies. The membranes were blocked with SuperBlock ${ }^{\circledR}$ T20 blocking buffer (Thermo Fisher Scientific, Inc., Waltham, MA, USA) for 60 min at room temperature. Polyclonal AHR antibody sheep IgG was obtained from R\&D Systems, Inc. (cat. no. AF6697; Minneapolis, MN, USA; dilution 1:500). Antibodies for other signaling proteins, including CYP1A1 (cat. no. sc-25304; dilution 1:1,000), NF-кB p65 (cat. no. sc-109; dilution 1:1,000), $\beta$-catenin (cat. no. sc-39350; dilution 1:1,000) and p53 (cat. no. sc-126; dilution 1:1,000) were obtained from Santa Cruz Biotechnology, Inc. (Dallas, TX, USA; dilution 1:1,000), and Ras (cat. no. 14429; dilution 1:1,000), $\beta$-actin (cat. no. 3700; dilution 1:1,000), retinoblastoma ( $\mathrm{Rb}$; cat. no. 9309; dilution 1:1,000) and p21 (cat. no. 2947; dilution 1:1,000) were purchased from Cell Signaling Technology, Inc.. Rabbit anti-regucalcin antibody was provided from Abcam (Cambridge, MA, USA; cat. no. ab213459; dilution 1:1,000), and it was used as described previously $(42,43,46)$. For immunoblotting with the aforementioned specific antibodies, the membranes were incubated with each primary antibody overnight at $4^{\circ} \mathrm{C}$, followed by horseradish peroxidase-conjugated secondary antibody (cat. nos. sc-2005 or sc-2305 for mouse and rabbit, respectively; Santa Cruz Biotechnology, Inc.; dilution 1:2,000) for $60 \mathrm{~min}$ at $4^{\circ} \mathrm{C}$. A total of 3 blots from independent experiments were scanned on an Epson Perfection 1660 Photo scanner, and the bands were quantified using ImageJ2 software (National Institutes of Health, Bethesda, MD, USA).

Statistical analysis. Statistical significance was determined using GraphPad InStat version 3 for Windows XP (GraphPad Software, Inc., La Jolla, CA, USA). Data are presented as the mean \pm standard deviation. Comparisons between two groups were performed using a Student's t-test. Furthermore, multiple comparisons were performed using one-way analysis of variance with Tukey-Kramer multiple comparisons post hoc test for parametric data as indicated. $\mathrm{P}<0.05$ was considered to indicate a statistically significant difference. 
A

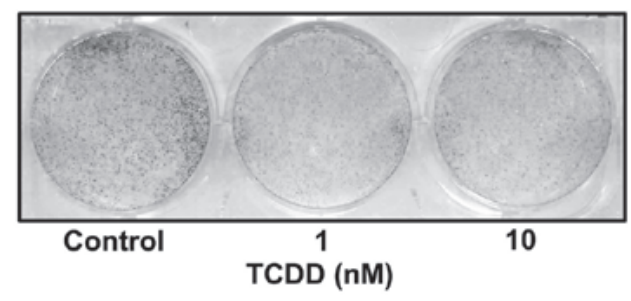

B

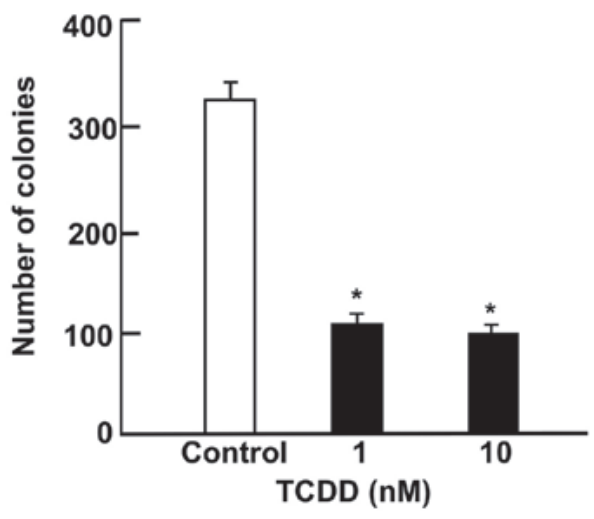

Figure 1. TCDD suppresses colony formation in RKO human colorectal cancer cells in vitro. Cells (1x10 ${ }^{3}$ cells/well) were seeded into 6-well plates and cultured in Dulbecco's modified Eagle's medium containing $10 \%$ fetal bovine serum, $1 \%$ penicillin/streptomycin and $1 \%$ fungizone in the presence of vehicle ( $1 \%$ dimethyl sulfoxide) or TCDD (1 or $10 \mathrm{nM})$ for 5 days when visible clones formed. The colonies were washed with PBS, fixed with methanol and then stained with $0.5 \%$ crystal violet. (A) Stained cells are presented as images (x10), and (B) the colonies containing $>50$ cells were counted under a microscope. ${ }^{*} \mathrm{P}<0.001$, vs. control. One-way analysis of variance and Tukey-Kramer post hoc test were used. TCDD, 2,3,7,8-tetrachlorodibenzo- $p$-dioxin.
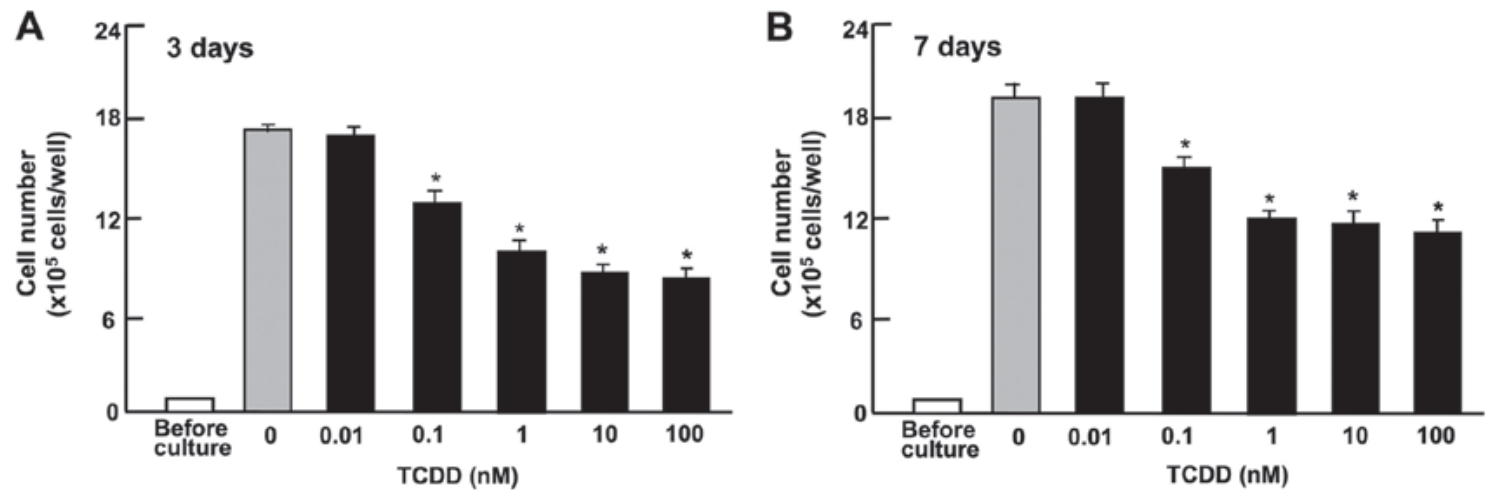

Figure 2. TCDD suppresses the proliferation of RKO human colorectal cancer cells in vitro. The cells (1x10 $0^{5}$ cells/well in 24-well plates) were cultured in Dulbecco's modified Eagle's medium containing $10 \%$ fetal bovine serum, $1 \%$ penicillin/streptomycin and $1 \%$ fungizone in the presence of vehicle (1\% dimethyl sulfoxide) or TCDD (0.01-100 nM) for (A) 3 or (B) 7 days. After culture, the numbers of attached cells were counted. Data are presented as mean \pm standard deviation obtained from 8 wells of 2 replicate plates per dataset using different dishes and cell preparations. ${ }^{*} \mathrm{P}<0.001$, vs. $0 \mathrm{nM}$ TCDD. One-way analysis of variance and Tukey-Kramer post hoc test were used. TCDD, 2,3,7,8-tetrachlorodibenzo-p-dioxin.

\section{Results}

$T C D D$ represses colony formation of $R K O$ cells. The effects of TCDD on colony formation of RKO human colorectal cancer cells in vitro was investigated. Visible clones of RKO cells were formed by culture for 5 days (Fig. 1). Subsequently, RKO cells were cultured in the presence of TCDD (1 or $10 \mathrm{nM})$. The number of colonies with $>50$ nuclei was significantly decreased by treatment with TCDD $(1$ or $10 \mathrm{nM})$ as depicted in Fig. 1A and B. Thus, TCDD exhibited a suppressive effect on the colony formation of RKO cells.

$T C D D$ suppresses the proliferation of RKO cells. To determine the effect of TCDD on cell growth, RKO cells were cultured in 24-well plates in the presence of TCDD (0.01-100 nM) for 3 or 7 days. The cells reached subconfluency after culturing for 3 days, and they reached confluency at 4-7 days of culture. Thus, cell growth was suppressed by the treatment with TCDD (0.1-100 nM) for 3 (Fig. 2A) or 7 (Fig. 2B) days.

TCDD stimulates the death of RKO cells. Subsequently, the effect of TCDD on the death of RKO cells in vitro was investigated. The cells were cultured for 3 days to reach subconfluency, and then exposed to TCDD (0.01-100 nM) for a further $24 \mathrm{~h}$. Treatment with TCDD (0.1-100 $\mathrm{nM})$ resulted in a decrease of attached cells (Fig. 3A and B), indicating that cell death is induced. In separate experiments, RKO cells that had reached subconfluency after culture for 3 days were incubated with a caspase- 3 inhibitor $(10 \mu \mathrm{M})$ and TCDD. The reduction of cell number caused by the treatment with TCDD $(1$ or $10 \mathrm{nM})$ was prevented in the presence of the inhibitor of caspase-3. Activation of caspase- 3 is demonstrated to induce DNA fragmentation associated with apoptosis (45). TCDD-induced cell death may be due to activation of caspase-3, which is known to induce DNA fragmentation associated with cell death (41). However, this remains to be elucidated using other methods.

Involvement of AHR signaling in the proliferation and death of RKO cells. To characterize the TCDD-induced repression of proliferation and promotion of death of RKO cells, the cells were cultured in the treatment with $\mathrm{CH} 223191$, a suppressor of AHR signaling (47). CH223191 (1 or $10 \mu \mathrm{M})$ did not have a significant effect on the proliferation or death of RKO 

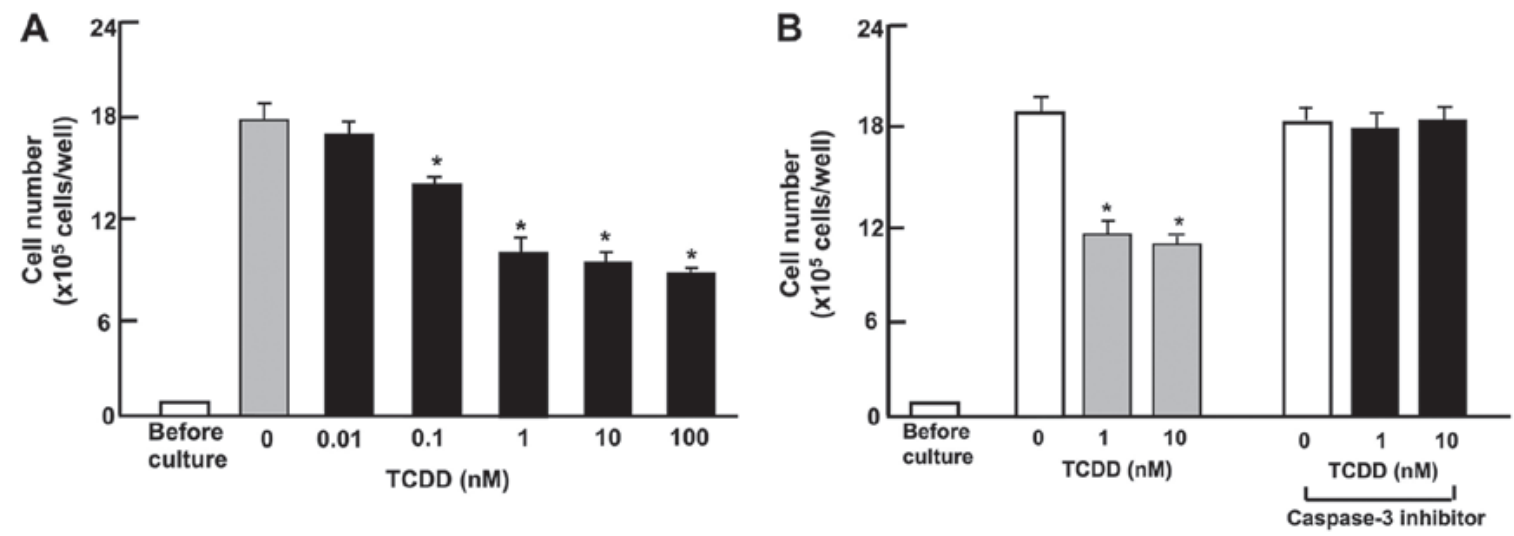

Figure 3. TCDD stimulates the death of RKO human colorectal cancer cells in vitro. (A) Cells $\left(1 \times 10^{5}\right.$ cells/well in 24-well plates) were cultured in DMEM containing $10 \%$ fetal bovine serum, $1 \%$ penicillin/streptomycin and $1 \%$ fungizone for 3 days to reach subconfluency, and the cells were then cultured in DMEM as aforementioned in the presence of vehicle (1\% DMSO) or TCDD (0.01-100 nM) for $24 \mathrm{~h}$. (B) After culture for 3 days, the cells were cultured in the presence of vehicle (1\% DMSO) or TCDD (1 or $10 \mathrm{nM})$ for $24 \mathrm{~h}$ with or without caspase-3 inhibitor $(10 \mu \mathrm{M})$. The numbers of attached cells were then counted. Data of cell number are presented as mean \pm standard deviation obtained from 8 wells of 2 replicate plates per dataset using different dishes and cell preparations. "P<0.001 vs. $0 \mathrm{nM}$ TCDD. One-way analysis of variance and Tukey-Kramer post hoc test were used. DMEM, Dulbecco's modified Eagle's medium; DMSO, dimethyl sulfoxide; TCDD, 2,3,7,8-tetrachlorodibenzo-p-dioxin.
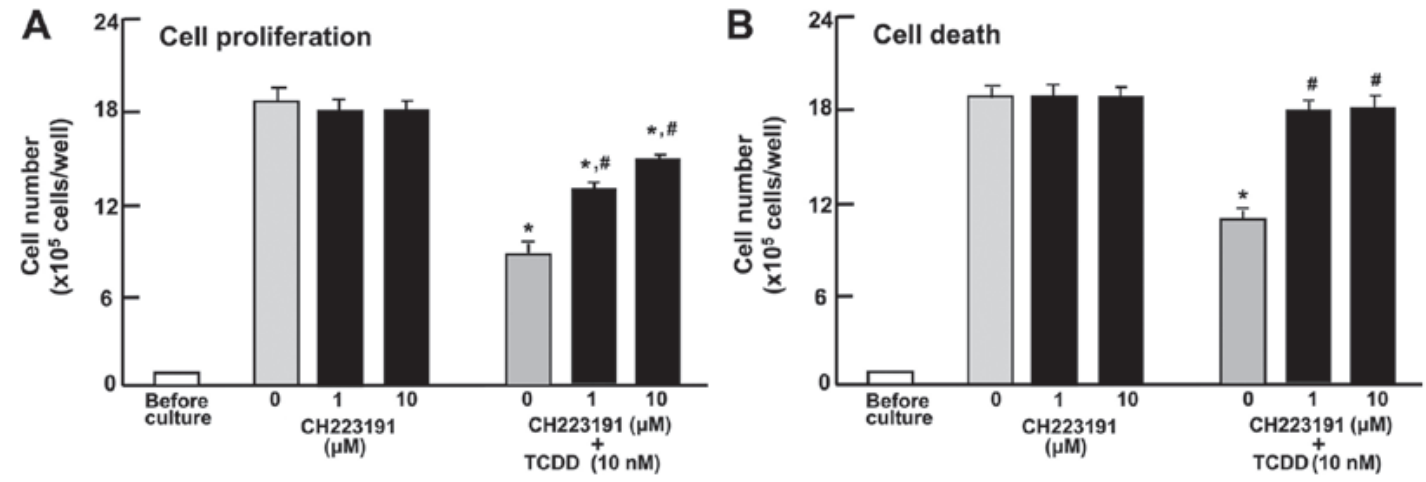

Figure 4. The AHR is involved in mediating the effects of TCDD on the proliferation and death of RKO human colorectal cancer cells. (A) The cells ( $1 \times 10^{5}$ cells/per well in 24-well plates) were cultured in DMEM containing $10 \%$ fetal bovine serum, $1 \%$ penicillin/streptomycin and $1 \%$ fungizone containing vehicle (1\% DMSO) or AHR inhibitor, CH223191 (1 or $10 \mu \mathrm{M})$, with or without TCDD $(10 \mathrm{nM})$ for 3 days. (B) The cells (1x10 5 cells/per well in $24-$ well plates) were cultured in DMEM as aforementioned for 3 days, and once the cells reached subconfluency, they were cultured in DMEM as aforementioned in the presence of vehicle (1\% DMSO) or CH223191 (1 or $10 \mu \mathrm{M})$. After $1 \mathrm{~h}$, TCDD $(10 \mathrm{nM})$ was added into the medium containing vehicle (1\% DMSO) or $\mathrm{CH} 223191(1$ or $10 \mu \mathrm{M})$, and the cells were cultured for a further $23 \mathrm{~h}$. The number of attached cells were then counted. Data are presented as mean \pm standard deviation obtained from 8 wells of 2 replicate plates per dataset using different dishes and cell preparations. ${ }^{*} \mathrm{P}<0.001$ vs. $0 \mu \mathrm{M} \mathrm{CH} 223191 .{ }^{*} \mathrm{P}<0.01$ vs. $0 \mu \mathrm{M} \mathrm{CH} 223191+10 \mathrm{nM}$ TCDD. One-way analysis of variance and Tukey-Kramer post hoc test were used. AHR, aryl hydrocarbon receptor; TCDD, 2,3,7,8-tetrachlorodibenzo-p-dioxin; DMEM, Dulbecco's modified Eagle's medium; DMSO, dimethyl sulfoxide.

cells (Fig. 4A and B). The repressive effect of TCDD (10 nM) on the proliferation and the promoting effect of TCDD $(10 \mathrm{nM})$ on the death of RKO cells were significantly blocked by CH223191 (1 or $10 \mathrm{nM}$; Fig. 4A or B). The effects of TCDD on cell proliferation were not completely blocked by the inhibitor (Fig. 4A); however, the promoting effects of TCDD on cell death were completely blocked (Fig. 4B). These results indicate that the effects of TCDD on the proliferation and death of RKO cells are partially mediated by AHR signaling.

$T C D D$ enhances the levels of proteins associated with tumor suppression in RKO cells. To characterize the mechanism of TCDD action, and determine whether or not TCDD treatment regulates the levels of key transcription factors, western blot analysis was used. AHR and CYP1A1 mRNAs were previously reported to be expressed in RKO cells in vitro $(34,35)$. It was demonstrated that the levels of AHR and CYP1A1 were altered by TCDD in RKO cells (Fig. 5A and B). Notably, treatment with TCDD $(10 \mathrm{nM})$ significantly elevated the levels of NF- $\mathrm{BB}$ p65 and $\beta$-catenin, which are crucial transcription factors associated with cell signaling (32). Additionally, TCDD treatment significantly elevated the levels of p53, Rb, p21 and regucalcin, which are known as pivotal repressors of the growth of tumor cells $(48,49)$ (Fig. 5C and D). TCDD $(10 \mathrm{nM})$ did not significantly alter the level of Ras, which acts upstream in Akt signaling (32,49) (Fig. 5A and B).

The effects of TCDD are suppressed in the regucalcin-overexpressing $R K O$ cells. Overexpression of regucalcin has been demonstrated to repress the enhanced proliferation and death of RKO cells in vitro (43). Therefore, the present study investigated whether the effects of TCDD were attenuated in regucalcin-overexpressing RKO cells in vitro. These cells exhibited increased levels of 

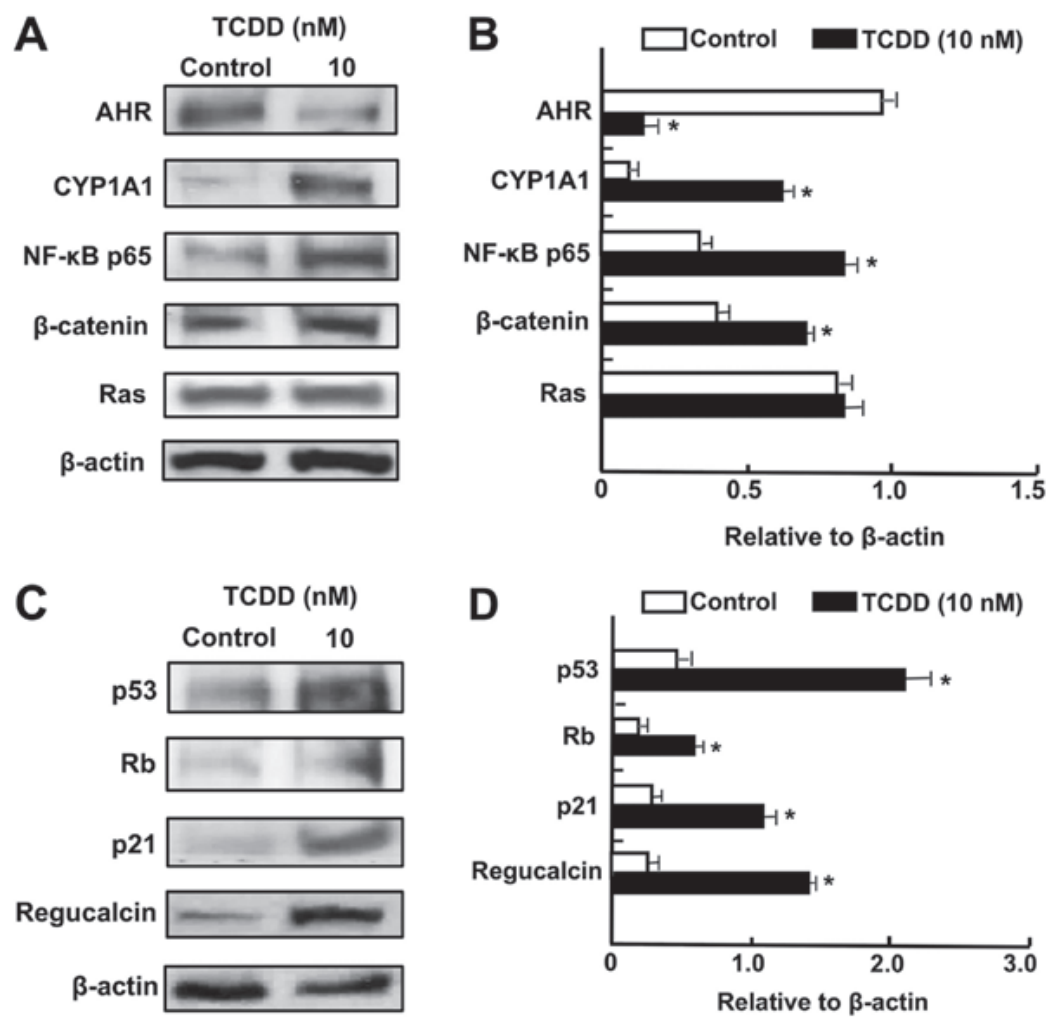

Figure 5. TCDD regulates the expression of proteins associated with AHR signaling in RKO human colorectal cancer cells in vitro. The cells (1x10 ${ }^{6}$ cells/dish) were cultured in Dulbecco's modified Eagle's medium containing 10\% fetal bovine serum, $1 \%$ penicillin/streptomycin and $1 \%$ fungizone in the presence of vehicle ( $1 \%$ dimethyl sulfoxide) or TCDD $(10 \mathrm{nM})$ for 3 days. Cell lysates were prepared and centrifuged, and $40 \mu \mathrm{g}$ of the supernatant protein per lane were separated by SDS-PAGE and transferred to nylon membranes for western blotting using specific antibodies against various proteins as indicated. Data represent a typical figure of three independent experiments using different cell preparations, and also are presented as mean \pm standard deviation. (A) Representative film image for cell signaling-associated proteins. (B) Relative to $\beta$-actin cell signaling-associated protein levels. (C) Representative film image of tumor suppressor proteins.(D) Relative to $\beta$-actin tumor suppressor proteins. "P<0.01 vs. control using Student's t-test. TCDD, 2,3,7,8-tetrachlorodibenzo- $p$-dioxin; AHR, aryl hydrocarbon receptor; NF- $\mathrm{BB}$, nuclear factor-kB; CYP1A1, cytochrome P450 family 1 subfamily A member 1; Rb, retinoblastoma.

A

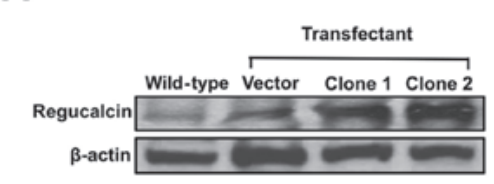

C

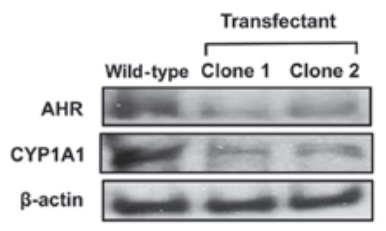

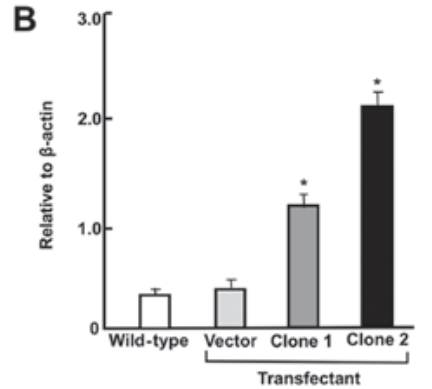

D

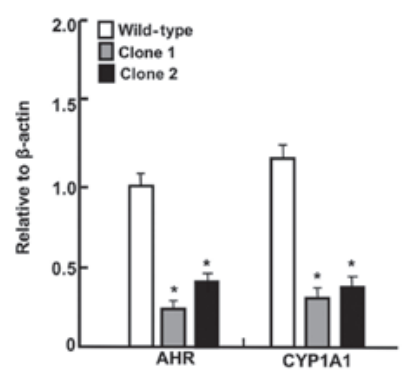

Figure 6. AHR and CYP1A1 levels are suppressed in regucalcin-overexpressing RKO human colorectal cancer cells in vitro. The wild-type RKO cells or regucalcin-overexpressing RKO cells $\left(1 \times 10^{6}\right.$ cells/per dish) were cultured in Dulbecco's modified Eagle's medium containing $10 \%$ fetal bovine serum, $1 \%$ penicillin/streptomycin and $1 \%$ fungizone in the presence or absence of vehicle ( $1 \%$ dimethyl sulfoxide) for 3 days. After culture, resulting cell lysates were centrifuged, and $40 \mu \mathrm{g}$ of the supernatant protein per lane were separated by SDS-PAGE and transferred to nylon membranes for western blotting using specific antibodies as indicated. Data represent a typical figure obtained from three independent experiments using different cell preparations, and also are presented as mean \pm standard deviation. (A) Representative film image for regucalcin. (B) Relative to $\beta$-actin regucalcin level. (C) Representative film image of AHR and CYP1A1. (D) Relative to $\beta$-actin AHR and CYP1A1 levels. "P<0.01 vs. wild-type using one-way analysis of variance and Tukey-Kramer post hoc test. AHR, aryl hydrocarbon receptor; CYP1A1, cytochrome P450 family 1 subfamily A member 1. 

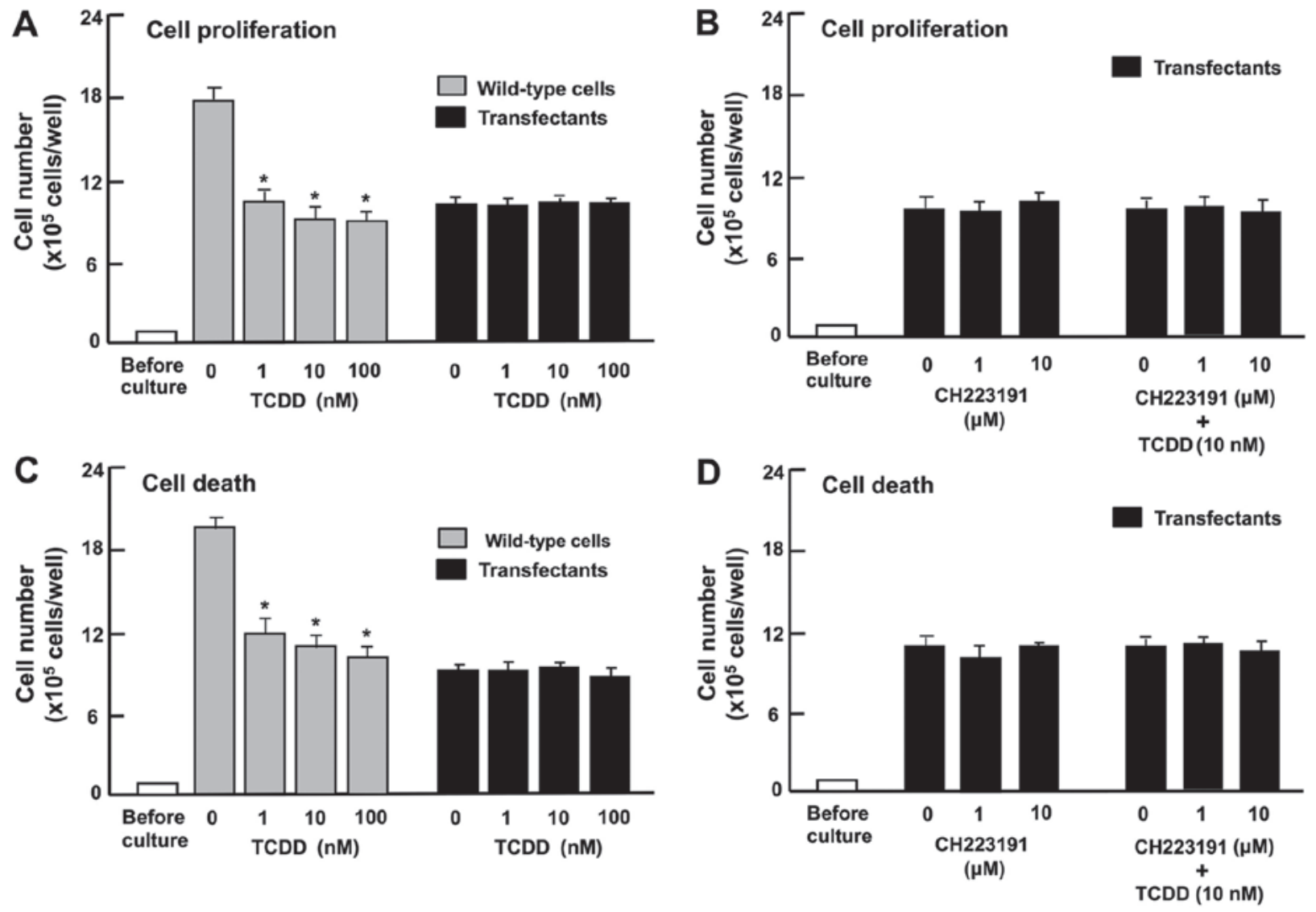

Figure 7. The effects of TCDD on the proliferation and death of RKO human colorectal cancer cells are attenuated by the overexpression of regucalcin in vitro. Wild-type cells or transfectants ( $1 \times 10^{5}$ cells/per well of 24-well plates) were cultured in DMEM containing $10 \% \mathrm{FBS}, 1 \% \mathrm{P} / \mathrm{S}$ and $1 \%$ fungizone in the presence of (A) vehicle (1\% DMSO) or TCDD $(1,10$ or $100 \mathrm{nM})$, or (B) vehicle (1\% DMSO) or CH223191 (1 or $10 \mu \mathrm{M})$ with or without TCDD (10 nM). In separate experiments, the wild-type cells or transfectants $\left(1 \times 10^{5}\right.$ cells/per $\mathrm{ml}$ of well) were cultured in DMEM as aforementioned for 3 days, and upon reaching subconfluence, the cells were cultured in DMEM containing $10 \%$ FBS, $1 \%$ P/S and $1 \%$ fungizone in the presence of (C) vehicle (1\% DMSO) or TCDD (1, 10 or $100 \mathrm{nM})$, or (D) vehicle (1\% DMSO) or CH223191 $(1$ or $10 \mu \mathrm{M})$ with or without TCDD $(10 \mathrm{nM})$ for $24 \mathrm{~h}$. After culture, the numbers of attached cells were counted. Data are presented as mean \pm standard deviation obtained from 8 wells of 2 replicate plates per dataset using different dishes and cell preparations. " $\mathrm{P}<0.001 \mathrm{vs}$. $0 \mathrm{~nm}$ TCDD in wild-type cells. One-way analysis of variance and Tukey-Kramer post hoc test were used. TCDD, 2,3,7,8-tetrachlorodibenzo- $p$-dioxin; DMEM, Dulbecco's modified Eagle's medium; DMSO, dimethyl sulfoxide; FBS, fetal bovine serum; P/S, penicillin/streptomycin.

regucalcin (Fig. 6A and B). Notably, regucalcin overexpression significantly suppressed CYP1A1 and AHR levels in RKO cells (Fig. 6C and D).

Subsequently, whether TCDD exhibits a repressive effect on proliferation and a promoting effect on cell death in the regucalcin-overexpressing RKO cells in vitro was investigated. Wild-type RKO cells or regucalcin-overexpressing cells were treated with TCDD $(1,10$ or $100 \mathrm{nM})$. Proliferation of wild-type RKO cells was significantly repressed by regucalcin overexpression (Fig. 7A). However, treatment with TCDD $(1,10$ or $100 \mathrm{nM}$ ), which suppressed the proliferation of wild-type RKO cells, did not exhibit a significant effect on the proliferation of transfectants with or without CH223191, an inhibitor of AHR signaling (Fig. 7B). Additionally, although treatment with TCDD $(1,10$ or $100 \mathrm{nM})$ significantly stimulated the death of wild-type RKO cells (Fig. 7C), it did not have a significant effect on the death of transfectants with or without CH223191, an inhibitor of AHR signaling (Fig. 7D). These observations indicate that regucalcin overexpression depresses AHR-dependent repression of proliferation and promotion of death of RKO cells.

Additionally, the effects of TCDD $(10 \mathrm{nM})$ on the levels of AHR, CYP1A1, p53, Rb and p21 in the regucalcin-overexpressing RKO cells were determined (Fig. 8A and B). TCDD treatment on transfectants cells did not appear to have a significant effect on CYP1A1 expression, since the effect of TCDD treatment on AHR-dependent CYP1A1 levels were depressed by regucalcin overexpression. Regucalcin overexpression has been demonstrated to increase the levels of p53, Rb and p21 in RKO cells (43) and other human cancer cells $(50,51)$. Notably, the effects of TCDD in increasing p53, Rb and p21 levels were potentiated by regucalcin overexpression. Since TCDD treatment increased regucalcin levels in wild-type RKO cells (Fig. 5), the effects of TCDD on increasing the levels of p53, Rb and p21 in RKO cells are likely to depend, at least in part, on the elevation in levels of regucalcin.

\section{Discussion}

Human colorectal cancer is diagnosed as the third most common cancer type in USA in 2016 and its 5-year survival rate remains poor at $55 \%$, in spite of the promotion of novel therapeutic strategies (3-8). Identification of novel biomarker targets may ultimately cause the prolongation of survival of patients with 
A

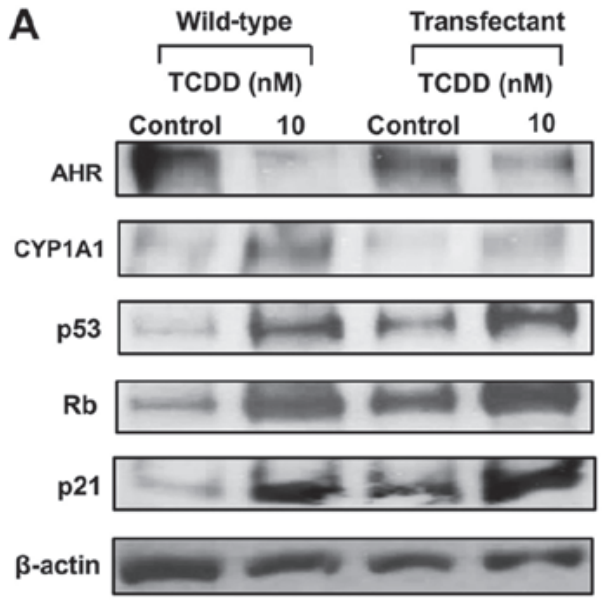

B

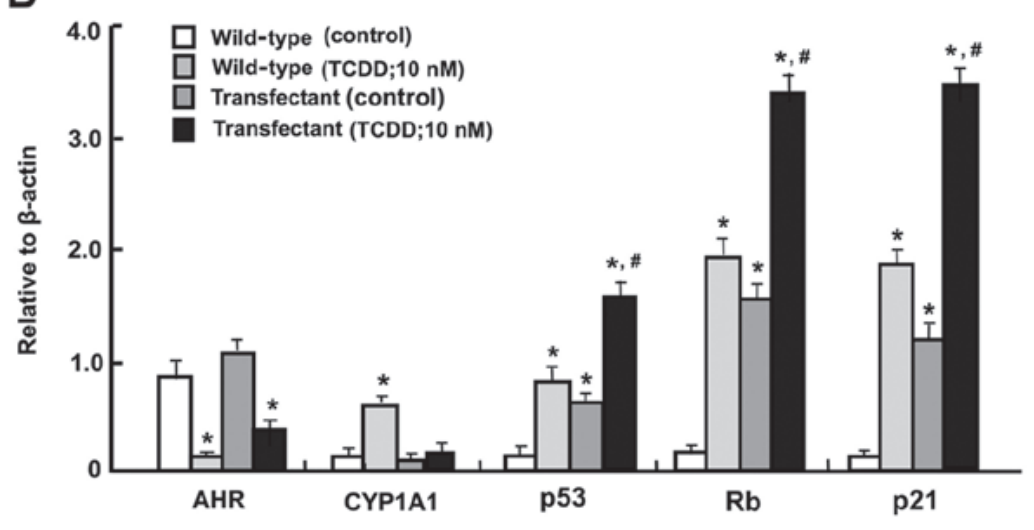

Figure 8. The TCDD-induced increase in CYP1A1 levels are suppressed in the regucalcin-overexpressing RKO human colorectal cancer cells in vitro. The wild-type RKO cells or regucalcin-overexpressing transfectants (1x10 6 cells/ dish) were cultured in Dulbecco's modified Eagle's medium containing $10 \%$ fetal bovine serum, $1 \%$ penicillin/streptomycin and $1 \%$ fungizone in the presence or absence of vehicle (1\% dimethyl sulfoxide) or TCDD (10 nM) for 3 days and then cell lysates were centrifuged. Subsequently, $40 \mu \mathrm{g}$ of the supernatant protein per lane were separated by SDS-PAGE and transferred to nylon membranes for western blotting using specific antibodies against the indicated proteins. Representative data from three independent experiments using different cell preparations are presented, and data are presented as mean \pm standard deviation. (A) Representative film images of the TCDD effect. (B) Presented relative to $\beta$-actin of the TCDD effect. " $\mathrm{P}<0.01$, vs. wild-type (control). ${ }^{*} \mathrm{P}<0.01$, vs. wild-type (TCDD; $10 \mathrm{nM}$ ) or transfectant (control). One-way analysis of variance and Tukey-Kramer post hoc test were used. TCDD, 2,3,7,8-tetrachlorodibenzo- $p$-dioxin; Rb, retinoblastoma; AHR, aryl hydrocarbon receptor; CYP1A1, cytochrome P450 family 1 subfamily A member 1 .

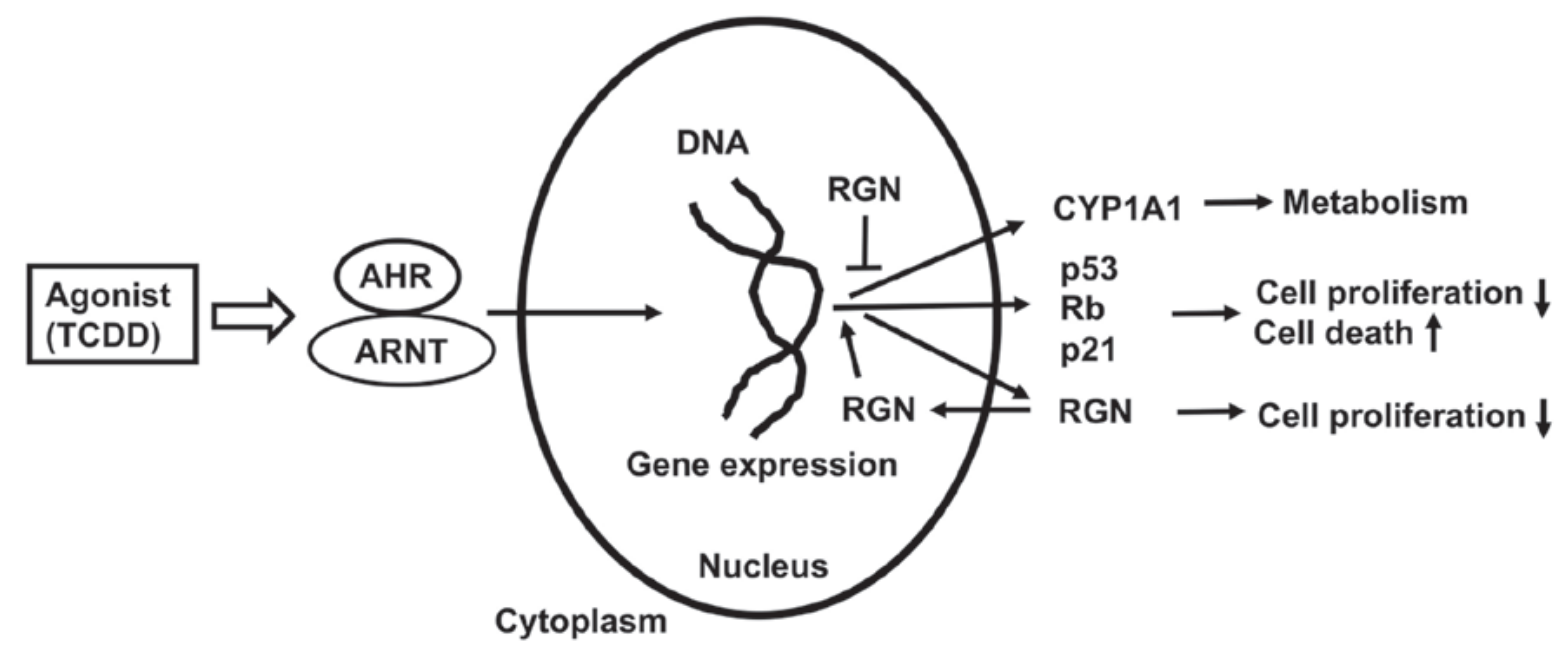

Figure 9. Schematic diagram of the mechanistic association between TCDD, AHR, CYP1A1, RGN and other molecules in RKO human colorectal cancer cells. TCDD activates AHR signaling by binding to ARNT. The complex is translocated into the nucleus and regulates expression of various genes. TCDD-activated AHR signaling enhances expression of various genes, including CYP1A1, RGN, p53, Rb and p21. Overexpressed RGN regulates the suppression of pathways of AHR signaling associated with CYP1A1, resulting in inhibition of metabolic pathways. Furthermore, overexpressed RGN enhances the expressions of p53, Rb and p21, which is increased via TCDD-activated AHR signaling, revealing a potential suppressive effect of cell proliferation and stimulatory effect of cell death. TCDD, 2,3,7,8-tetrachlorodibenzo- $p$-dioxin; Rb, retinoblastoma; AHR, aryl hydrocarbon receptor; CYP1A1, cytochrome P450 family 1 subfamily A member 1; RGN, regucalcin; ARNT, AHR nuclear translocator.

colorectal cancer (9). In the present study, it was demonstrated that TCDD treatment suppresses the growth and proliferation, and stimulates the death, of RKO human colorectal cancer cells. These effects of TCDD were demonstrated to be blocked by the treatment with $\mathrm{CH} 223191$, an inhibitor of AHR signaling (47), indicating that the action of TCDD is at least partially mediated through the AHR signaling pathway. The observations thus demonstrate that the enhanced AHR signaling serves a suppressive role in the development of human colorectal cancer cells.

To investigate the mechanism of action of TCDD, it was first demonstrated that the AHR and CYP1A1 proteins are present in RKO cells, consistent with previous studies, demonstrating that these mRNAs are expressed in these cells in vitro $(34,35)$. In the present study, TCDD treatment was demonstrated to be caused a reduction of AHR levels and an elevation of CYP1A1 levels in the cytosol, including endoplasmic reticulum of RKO cells. TCDD treatment has been demonstrated to enhance the translocation of cytoplasmic AHR into the nucleus and increases CYP1A1 expression $(11,12,32)$. Notably, TCDD treatment also elevated the levels of NF- $\kappa \mathrm{B}$ p65 and $\beta$-catenin, which are crucial transcription factors implicated in the manifold process of cell signaling, and the levels of $\mathrm{p} 53, \mathrm{Rb}$, 
p21 and regucalcin, which are pivotal repressors of the growth of tumor cells $(48,49)$. TCDD treatment did not change the level of Ras, which acts upstream in Akt signaling. $\beta$-catenin has been demonstrated to enhance regucalcin expression in HepG2 cells in vitro (52). It has also been reported that p53 modulates Hsp90 ATPase activity, which is implicated in AHR-dependent activation of gene expression (53). These signaling factors may be partially implicated in mediating the action of TCDD on the proliferation and death of RKO cells. Whether or not these molecules serve a role in the expression of the AHR gene remains to be elucidated.

Furthermore, it was determined that the effects of TCDD are attenuated in the regucalcin-overexpressing RKO cells. Overexpression of regucalcin has been demonstrated to repress the proliferation and death of RKO cells in vitro (43). Notably, regucalcin overexpression was demonstrated to decrease AHR and CYP1A1 levels in RKO cells, indicating that overexpressed regucalcin suppresses AHR signaling in RKO cells. Regucalcin has been indicated to translocate from the cytoplasm to nucleus in various types of normal and cancer cells, including liver and kidney $(48,49)$, and it regulates the gene expressions of various proteins, including p53 and $\mathrm{Rb}$, apparently acting as a novel transcriptional factor via binding nuclear DNA $(48,49,54)$. Thus, it was considered that regucalcin serves a crucial role as a novel suppressor of AHR signaling. Notably, it was considered that TCDD treatment, which exhibits a repressive effect on the proliferation and a promoting effect on the death of wild-type RKO cells, did not have such effects in regucalcin-overexpressing RKO cells. These results support the view that AHR signaling is depressed by regucalcin overexpression in $\mathrm{RKO}$ cells in vitro.

Subsequently, whether the action of TCDD on the levels of AHR, CYP1A1, p53, Rb and p21 was attenuated in regucalcin-overexpressing RKO cells was investigated. Whereas TCDD treatment decreased AHR levels and increased CYP1A1 levels, these effects were determined to be depressed by regucalcin overexpression, indicating that AHR signaling activated by TCDD, an agonist, is suppressed by regucalcin overexpression. Notably, the effects of TCDD in increasing p53, Rb and p21 levels were demonstrated to be potentiated by regucalcin overexpression. Overexpression of regucalcin has been demonstrated to increase the levels of p53, Rb and p21 in RKO cells (43), and in other types of human cancer cells $(50,51)$. Additionally, TCDD treatment increased regucalcin levels in wild-type RKO cells. These observations indicate that the action of TCDD in increasing the levels of p53, Rb and p21 in RKO cells are mediated, at least in part, via increases in regucalcin. Additionally, regucalcin overexpression suppressed the activation of AHR signaling associated with CYP1A1 expression. It is not known whether the deficiency of regucalcin enhances AHR signaling, although this remains to be elucidated using regucalcin siRNA. It is possible that the activation of AHR signaling enhances regucalcin gene expression, and that increased regucalcin suppresses AHR signaling pathways. This suppressive effect may result in inhibition of metabolic pathways associated with CYP1A1. The schematic diagram to demonstrate the mechanistic association between TCDD, AHR and regucalcin is depicted in Fig. 9. Collectively, AHR signaling may serve a crucial role in suppression of the growth of colorectal cancer cells, probably mediated via manifold molecules linked to tumor suppression.

In conclusion, the present study demonstrates that the agonist of AHR signaling, TCDD, suppresses the growth of human colorectal cancer cells and stimulates their death, via AHR signaling, probably as the result of stimulation of manifold molecules in regulating various signaling pathways. Therefore, targeting AHR signaling may cause an antitumor effect in vivo, providing a novel strategic tool for therapy of various cancer types.

\section{Acknowledgements}

Not applicable.

\section{Funding}

The present study was supported in part from a NIH grant (grant no. 1 RO1ES024434; received by OH).

\section{Availability of data and materials}

The datasets used during the present study are available from the corresponding author upon reasonable request.

\section{Authors' contributions}

MY conceived and designed the study. MY performed the experiment, and MY and $\mathrm{OH}$ discussed the data. MY wrote the manuscript, and $\mathrm{OH}$ reviewed and edited the manuscript. All authors read and approved the manuscript, and agree to be accountable for all aspects of the research in ensuring that the accuracy or integrity of any part of the study are appropriately investigated and resolved.

\section{Ethics approval and consent to participate}

Not applicable.

\section{Patient consent for publication}

Not applicable.

\section{Competing interests}

The authors declare that they have no competing interests.

\section{References}

1. Medema JP and Vermeulen L: Microenvironmental regulation of stem cells in intestinal homeostasis and cancer. Nature 474: 318-326, 2011.

2. Porter MG and Stoeger SM: Atypical colorectal neoplasms. Surg Clin North Am 97: 641-656, 2017.

3. American Cancer Society: Cancer facts and figures 2016. American Cancer Society, Atlanta, GA, 2016. https://www. cancer.org/research/cancer-facts-statistics/all- cancer-factsfigures/cancer-facts-figures-2016.html. Accessed January 24, 2017.

4. Siegel RL, Miller KD and Jemal A: Cancer statistics, 2016. CA Cancer J Clin 66: 7-30, 2016.

5. Brenner H, Kloor M and Pox CP: Colorectal cancer. Lancet 383: 1490-1502, 2014. 
6. Alnabulsi A and Murray GI: Integrative analysis of the colorectal cancer proteome: Potential clinical impact. Expert Rev Proteomics 13: 1-11, 2016.

7. Alnabulsi A, Swan R, Cash B, Alnabulsi A and Murray GI: The differential expression of omega-3 and omega- 6 fatty acid metabolising enzymes in colorectal cancer and its prognostic significance. Br J Cancer 116: 1612-1620, 2017.

8. Carini F, Mazzola M, Rappa F, Jurjus A, Geagea AG, Al Kattar S, Bou-Assi T, Jurjus R, Damiani P, Leone A, et al: Colorectal carcinogenesis: Role of oxidative stress and antioxidants. Anticancer Res 37: 4759-4766, 2017.

9. Colussi D, Brandi G, Bazzoli F and Ricciardiello L: Molecular pathways involved in colorectal cancer: Implications for disease behavior and prevention. Int J Mol Sci 14: 16365-16385, 2013.

10. Kudryavtseva AV, Lipatova AV, Zaretsky AR, Moskalev AA, Fedorova MS, Rasskazova AS, Shibukhova GA, Snezhkina AV, Kaprin AD, Alekseev BY, et al: Important molecular genetic markers of colorectal cancer. Oncotarget 7: 53959-53983, 2016.

11. Hankinson O: The aryl hydrocarbon receptor complex. Annu Rev Pharmacol Toxicol 35: 307-340, 1995.

12. Hankinson O: Role of coactivators in transcriptional activation by the aryl hydrocarbon receptor. Arch Biochem Biophys 433: 379-386, 2005

13. Denison MS and Nagy SR: Activation of the aryl hydrocarbon receptor by structurally diverse exogenous and endogenous chemicals. Annu Rev Pharmacol Toxicol 43: 309-334, 2003.

14. Nguyen LP and Bradfield CA: The search for endogenous activators of the aryl hydrocarbon receptor. Chem Res Toxicol 21: 102-116, 2008.

15. Ronnekleiv-Kelly SM, Nukaya M, Díaz-Díaz CJ, Megna BW, Carney PR, Geiger PG and Kennedy GD: Aryl hydrocarbon receptor-dependent apoptotic cell death induced by the flavonoid chrysin in human colorectal cancer cells. Cancer Lett 370: 91-99, 2016.

16. Ikuta T, Kurosumi M, Yatsuoka T and Nishimura Y: Tissue distribution of aryl hydrocarbon receptor in the intestine: Implication of putative roles in tumor suppression. Exp Cell Res 343: 126-134, 2016

17. Pastorková B, Vrzalová A, Bachleda $\mathrm{P}$ and Dvořák Z: Hydroxystilbenes and methoxystilbenes activate human aryl hydrocarbon receptor and induce CYP1A genes in human hepatoma cells and human hepatocytes. Food Chem Toxicol 103: 122-132, 2017.

18. Safe S, Lee SO and Jin UH: Role of the aryl hydrocarbon receptor in carcinogenesis and potential as a drug target. Toxicol Sci 135: $1-16,2013$.

19. Mulero-Navarro S and Fernandez-Salguero PM: New trends in aryl hydrocarbon receptor biology. Front Cell Dev Biol 4: 45, 2016.

20. Stejskalova L and Pavek P: The function of cytochrome P450 1A1 enzyme (CYP1A1) and aryl hydrocarbon receptor (AhR) in the placenta. Curr Pharm Biotechnol 12: 715-730, 2011.

21. Nukaya M, Moran S and Bradfield CA: The role of the dioxin-responsive element cluster between the Cypla1 and Cyp1a2 loci in aryl hydrocarbon receptor biology. Proc Nat Acad Sci USA 106: 4923-4928, 2009.

22. Pierre S, Chevallier A, Teixeira-Clerc F, Ambolet-Camoit A, Bui LC, Bats AS, Fournet JC, Fernandez-Salguero P, Aggerbeck M, Lotersztajn S, et al: Aryl hydrocarbon receptor-dependent induction of liver fibrosis by dioxin. Toxicol Sci 137: 114-124, 2014.

23. Wu D, Nishimura N, Kuo V, Fiehn O, Shahbaz S, Van Winkle L, Matsumura F and Vogel CF: Activation of aryl hydrocarbon receptor induces vascular inflammation and promotes atherosclerosis in apolipoprotein $\mathrm{E}^{-/}$mice. Arterioscler Thromb Vasc Biol 31: 1260-1267, 2011.

24. Brito JS, Borges NA, Esgalhado M, Magliano DC, Soulage CO and Mafra D: Aryl hydrocarbon receptor activation in chronic kidney disease: Role of uremic toxins. Nephron 137: 1-7, 2017.

25 . Esser $C$ : The aryl hydrocarbon receptor in immunity: Tools and potential. Methods Mol Biol 1371: 239-257, 2016.

26. Murray IA, Patterson AD and Perdew GH: Aryl hydrocarbon receptor ligands in cancer: Friend and foe. Nat Rev Cancer 14 801-814, 2014

27. Barouki R, Coumoul X and Fernandez-Salguero PM: The aryl hydrocarbon receptor, more than a xenobiotic-interacting protein. FEBS Lett 581: 3608-3615, 2007.
28. Moennikes O, Loeppen S, Buchmann A, Andersson P, Ittrich C, Poellinger L and Schwarz M: A constitutively active dioxin/aryl hydrocarbon receptor promotes hepatocarcinogenesis in mice. Cancer Res 64: 4707-4710, 2004

29. Fan Y, Boivin GP, Knudsen ES, Nebert DW, Xia Y and Puga A The aryl hydrocarbon receptor functions as a tumor suppressor of liver carcinogenesis. Cancer Res 70: 212-220, 2010.

30. Mathew LK, Simonich MT and Tanguay RL: AHR-dependent misregulation of Wnt signaling disrupts tissue regeneration. Biochem Pharmacol 77: 498-507, 2009.

31. Jackson DP, Li H, Mitchell KA, Joshi AD and Elferink CJ: Ah receptor-mediated suppression of liver regeneration through NC-XRE-driven p21 Cip1 expression. Mol Pharmacol 85: 533-541, 2014.

32. Yamaguchi $\mathrm{M}$ and Hankinson O: 2,3,7,8-Tetrachlorodibenzo$p$-dioxin suppresses the growth of human liver cancer HepG2 cells in vitro: Involvement of cell signaling factors. Int J Oncol 53: 1657-1666, 2018.

33. Harper PA, Prokipcak RD, Bush LE, Golas CL and Okey AB: Detection and characterization of the Ah receptor for 2,3,7,8-tetrachlorodibenzo- $p$-dioxin in the human colon adenocarcinoma cell line LS180. Arch Biochem Biophys 290: 27-36, 1991.

34. Megna BW, Carney PR, Nukaya M, Geiger P and Kennedy GD: Indole-3-carbinol induces tumor cell death: Function follows form. J Surg Res 204: 47-54, 2016.

35. Megna BW, Carney PR, Depke MG, Nukaya M, McNally J, Larsen L, Rosengren RJ and Kennedy GD: The aryl hydrocarbon receptor as an antitumor target of synthetic curcuminoids in colorectal cancer. J Surg Res 213: 16-24, 2017.

36. Wohak LE, Krais AM, Kucab JE, Stertmann J, Øvrebø S, Seidel A, Phillips DH and Arlt VM: Carcinogenic polycyclic aromatic hydrocarbons induce CYP1A1 in human cells via a p53-dependent mechanism. Arch Toxicol 90: 291-304, 2016.

37. Li W, Harper PA, Tang BK and Okey AB: Regulation of cytochrome P450 enzymes by aryl hydrocarbon receptor in human cells: CYP1A2 expression in the LS180 colon carcinoma cell line after treatment with 2,3,7,8-tetrachlorodibenzo- $p$-dioxin or 3-methylcholanthrene. Biochem Pharmacol 56: 599-612, 1998.

38. Xie G and Raufman J-P: Role of the aryl hydrocarbon receptor in colon neoplasia. Cancers (Basel) 7: 1436-1446, 2015.

39. Kawajiri K, Kobayashi Y, Ohtake F, Ikuta T, Matsushima Y, Mimura J, Pettersson S, Pollenz RS, Sakaki T, Hirokawa T, et al: Aryl hydrocarbon receptor suppresses intestinal carcinogenesis in $\mathrm{Apc}^{\mathrm{Min} /+}$ mice with natural ligands. Proc Natl Acad Sci USA 106: 13481-13486, 2009.

40. Fang Z, Tang Y, Fang J, Zhou Z, Xing Z, Guo Z, Guo X, Wang W, Jiao W, Xu Z and Liu Z: Simvastatin inhibits renal cancer cell growth and metastasis via AKT/mTOR, ERK and JAK2/STAT3 pathway. PLoS One 8: e62823, 2013.

41. Wang K, Li Y, Jiang YZ, Dai CF, Patankar MS, Song JS and Zheng J: An endogenous aryl hydrocarbon receptor ligand inhibits proliferation and migration of human ovarian cancer cells. Cancer Lett 340: 63-71, 2013.

42. Misawa H, Inagaki S and Yamaguchi M: Suppression of cell proliferation and deoxyribonucleic acid synthesis in the cloned rat hepatoma H4-II-E cells overexpressing regucalcin. J Cell Biochem 84: 143-149, 2001.

43. Yamaguchi M, Osuka S and Murata T: Prolonged survival of patients with colorectal cancer is associated with a higher regucalcin gene expression: Overexpression of regucalcin suppresses the growth of human colorectal carcinoma cells in vitro. Int J Oncol 53: 1313-1322, 2018.

44. Yamaguchi M and Daimon Y: Overexpression of regucalcin suppresses cell proliferation in cloned rat hepatoma H4-II-E cells: Involvement of intracellular signaling factors and cell cycle-related genes. J Cell Biochem 95: 1169-1177, 2005.

45. Izumi T and Yamaguchi M: Overexpression of regucalcin suppresses cell death in cloned rat hepatoma H4-II-E cells induced by tumor necrosis factor-alpha or thapsigargin. J Cell Biochem 92: 296-306, 2004.

46. Yamaguchi $M$ and Isogai $M$ : Tissue concentration of calcium-binding protein regucalcin in rats by enzyme-linked immunoadsorbent assay. Mol Cell Biochem 122: 65-68, 1993

47. Choi E-Y, Lee H, Dingle RWC, Kim KB and Swanson HI: Development of novel CH223191-based antagonists of the aryl hydrocarbon receptor. Mol Pharmacol 81: 3-11, 2012.

48. Tsurusaki Y and Yamaguchi M: Role of regucalcin in liver nuclear function: Binding of regucalcin to nuclear protein or DNA and modulation of tumor-related gene expression. Int J Mol Med 14: 277-281, 2004. 
49. Yamaguchi M: Suppressive role of regucalcin in liver cell proliferation: Involvement in carcinogenesis. Cell Prolif 46: 243-253, 2013.

50. Yamaguchi M, Osuka S, Weitzmann MN, El-Rayes BF, Shoji M and Murata T: Prolonged survival in pancreatic cancer patients with increased regucalcin gene expression: Overexpression of regucalcin suppresses the proliferation in human pancreatic cancer MIA PaCa-2 cells in vitro. Int J Oncol 48: 1955-1964, 2016.

51. Yamaguchi M, Osuka S, Weitzmann MN, El-Rayes BF, Shoji M and Murata T: Prolonged survival in hepatocarcinoma patients with increased regucalcin gene expression: HepG2 cell proliferation is suppressed by overexpression of regucalcin in vitro. In J Oncol 49: 1686-1694, 2016.
52. Nejak-Bowen KN, Zeng G, Tan X, Cieply B and Monga SP: Beta-catenin regulates vitamin $\mathrm{C}$ biosynthesis and cell survival in murine liver. J Biol Chem 284: 28115-28127, 2009.

53. Kochhar A, Kopelovich L, Sue E, Guttenplan JB, Herbert BS, Dannenberg AJ and Subbaramaiah K: p53 modulates Hsp90 ATPase activity and regulates aryl hydrocarbon receptor signaling. Cancer Prev Res (Phila) 7: 596-606, 2014.

54. Yamaguchi M: Role of regucalcin in cell nuclear regulation: Involvement as a transcription factor. Cell Tissue Res 354: 331-341, 2013. 